\title{
Political competition, relative deprivation, and perceived threat: a research note on anti- Christian violence in India
}

\author{
Chad Bauman \& Tamara G.J. Leech
}

\begin{abstract}
A preliminary subnational statistical analysis of violence against Christians in contemporary India, this article suggests that whereas the data provide very little support for simple, demographic explanations of this violence, they do more robustly support theories emphasizing the relative status of ethnic and religious minorities (vis-à-vis majorities) and the perception, among Hindus, that Christians (and other minorities) represent a threat to their numerical, political and economic strength.
\end{abstract}

Keywords: Hindu, Christian, ethnic violence, India, nationalism

This is the author's manuscript of the article published in final edited form as:

Bauman, C., \& Leech, T. (2012). Political competition, relative deprivation, and perceived threat: a research note on anti-Christian violence in India. Ethnic and Racial Studies, 35(12), 2195-2216. http://doi.org/10.1080/01419870.2011.631558 


\section{Political competition, relative deprivation, and perceived threat: a research note on anti- Christian violence in India}

\section{Introduction}

While Hindu-Muslim violence has been extensively analysed, Hindu-Christian violence was until recently so rare that scholars have seldom investigated the phenomenon. In the last decade, however, violence between Hindu and Christian groups in India has increased substantially. Christians are now attacked, on average, over 200 times a year, although the scope and severity of those attacks varies widely. In this research note we provide a descriptive analysis of violence against Christians, with the intention of encouraging and guiding future research. Our analysis raises as many questions as it answers. But that, essentially, is the point.

We begin with an investigation of population dynamics that could contribute to higher levels of violence. Subsequently, we analyse indicators specific to ethnicity and socioeconomic status (e.g. the size and growth of religious, caste and tribal groups). Next, we move on to explore indicators of political power and competition between Hindu nationalists and other political bodies. Finally, we end with an examination of indicators of human capital and relative deprivation among the Hindu population. As we note in our concluding remarks, our data provide some minimal support for simple (e.g. demographic), macro-level explanations, particularly with regard to regions like the relatively less-developed north. However, the data also suggest that such explanations are unsustainable at the national level, where only theories focused on the relative status of ethnic minorities (vis-à-vis dominant groups) and on perceived threat receive consistent support.

\section{Context and background}

Thugs, criminals and opportunists surely factor into anti-minority violence in India (Brass 2003; Pandey 2006), but various Hindu nationalist organizations' direct and indirect support of violence against Christians is also widely acknowledged (Sarkar 1999; Aaron 2002; Hardiman 2002; Brass 2003). These organizations are known collectively as the Sangh Parivar, which includes a number of social, religious and cultural organizations as well as India's most powerful opposition party, the Bharatiya Janata Party (Indian People's Party, BJP). All of these groups espouse, to varying degrees, the ideology of Hindutva ('Hindu-ness') as the basis for national unity, and therefore suspect 'foreign' religious minorities, particularly Muslims and Christians, of potential disloyalty. Concerns about Christianity are exacerbated by what is perceived to be its aggressive proselytizing (Jaffrelot 2007). While violence against Muslims has been a relatively regular feature of independent India, violence against Christians has become a significant issue only since the late 1990 s.

Given Hindu nationalists' common coupling of Islam and Christianity as 'foreign religions', we place violence against Christians into the theoretical contexts promoted in the literature on Hindu-Muslim violence and political violence more generally. The most significant recent statistical analyses of Hindu-Muslim violence, in our view, are those by Henrik Urdal (2008), Ashutosh Varshney (2002) and Steven Wilkinson (2004). Their work guides the present analysis in important ways. Our data will therefore, we hope, not only reveal something about the nature 
of Hindu-Christian violence, but also, at least indirectly, about the extent to which their theories, advanced in the context of Hindu-Muslim violence, are useful in the context of Hindu-Christian violence.

While our investigation is preliminary, it proceeds with three comparative advantages. First, while much of the extant work on political violence is based on comparative national statistics, and is therefore unable to identify, interpret or account for intra-national discrepancies, our research is based on state-level analyses. Second, we assess Hindu-Christian violence, a species of ethnic violence, 1 separately from other forms of political violence (e.g. civil wars, rebellions, pogroms). Few studies on religious minorities make this necessary distinction in their analytic plan. Among other issues, incidents of ethnic violence tend to be both more transitory and more geographically limited than other forms of political violence (Froystad 2009). Finally, whereas many larger studies examine only violent regions, looking for their commonalities, our analysis takes into consideration how peaceful states differ from violent states. As Varshney (2002, p. 6) has suggested, 'until we study ethnic peace, we will not be able to have a good theory of ethnic conflict.'

\section{Data}

Our database contains information on 223 violent incidents in 2007 and 279 violent incidents in 2008 (502 total incidents). 'Violent', as we defined it, includes: (1) any form of physical violence or coercion (e.g. murder, beatings, kidnapping); and (2) any act that could intentionally or inadvertently harm an individual or group (e.g. arson, throwing rocks through windows, etc.). The vast majority of the incidents recorded in the database fall into category 1 . In addition, we included only incidents with specific information on date, location and the identity of victims. For example, if a report on a riot indicated, in a general way, that fifty homes had been burned down in a certain region (as was often the case in the reporting on riots), nothing was recorded. However, if, for example, the report mentioned that a pastor's house had been burned down in a specific village on a specific date, then the incident was recorded. Furthermore, we recorded an incident only once, no matter how many victims were affected. This method of recording helps explain why Orissa, which experienced significant Hindu-Christian rioting in late 2007 and in 2008, was only fourth (48) in terms of total incidents in 2007-8, after Karnataka (167), Andhra Pradesh (61) and Madhya Pradesh (58). It also means, however, that incidents of riot violence have been given proportionately less weight in our statistical analysis. Finally, we focused on violence against Christians, and therefore did not include in our database incidents of violence or retaliation by Christians against Hindus, even though several such incidents did occur during this period.

The literature on Hindu-Muslim violence focuses mostly on the grand spectacle of the largescale riot. Hindu-Christian violence has its spectacles, such as the riots in Dangs, Gujarat (1998), and a series of riots in the Kandhamal region of Orissa (2007-8) (Aaron 2002; Chatterji 2009; Bauman 2010). Although serious, particularly in the case of Kandhamal, none of the HinduChristian riots have approached the worst Hindu-Muslim conflicts in severity, and HinduChristian riots of this scale remain relatively rare. Because of this, Hindu-Christian violence is typified by the smaller, more limited incident. These incidents might be linked to or at times inspired by broader, more regional upheavals. But they are more regularly isolated events. Therefore, unlike the database developed by Varshney (2002) and Wilkinson (2004), and used 
by Urdal (2008), which focuses on large-scale Hindu-Muslim riots, our database contains a record of individual incidents of violence against Christians. These incidents expand the current quantitative depiction of anti-minority violence to include the routine (Pandey 2006) nature of Hindu-Christian violence. Hindu-Christian violence is routine not only in the sense of everyday, but also in the sense of regularized and routinized in the treatment of Christians and in the framing of Christianity as a threatening minority.

We opted to use media data sources because the Government of India does not publish statistics on violence against Christians as such. Information obtained through keyword searches of news sources was supplemented by that found on more systematic incident lists maintained by three organizations, all of them Christian: Compass Direct News (www.compassdirect.org), the Global Council of Indian Christians (www.persecution.in) and Christian Solidarity Worldwide (www.Csw.org.uk).

It would have been preferable, in this preliminary analysis, to pair data culled from media reports with government statistics, if they had existed. Although official government records on ethnic violence are notoriously problematic (Varshney 2002), data compiled by our method could be compromised as well. Pandey has argued persuasively that colonial British narrations of 'communal' violence tended to perpetuate and reify the self-justifying colonial assertion that inter-religious conflict was endemic to pre-British India and could only be exterminated through strong-handed colonial rule and 'civilizing' efforts. Pandey (1990, p. 102) writes: 'Even the "bare facts" of the situation were constructed, and constructed out of the prejudices, biases and “common sense” of the writers.' Similarly, Christian media narrations of anti-Christian violence tend to adhere to a well-rehearsed master narrative that frames 'persecution' of Christians in rather simple terms as the unprovoked work of Hindu nationalists opposed to religious freedom and secular governance, and necessitating/justifying intervention not only from India's government, but also from foreign powers, the United Nations (UN), non-governmental organizations (NGOs) and Christians worldwide. This master narrative plasters over a variety of more complicated facts.

It is of course also a possibility that in the service of perpetuating this master narrative, Christian media sources have inflated the number and severity of incidents. That said, while the details of the incidents recorded in these media outlets may have been stereotyped in ways just described, we have no reason to believe that they have been fabricated. Indeed, in our own travels in India we have collected reports of dozens of similar stories that were not recorded at all by the media. Moreover, we have no reason to believe that instances of fabrication, if they occurred, would favour one state over another. There is, however, a possible state-by-state bias in the fact that some Christian organizations might be better than others at getting violence against their members reported in news sources. If these denominations or missionary organizations were concentrated in a specific state or region, then the number of incidents could become inflated in that location. However, given the number of incidents recorded and the variety of denominations/organizations targeted in the incidents, we believe this potential bias has had at most a minimal effect, and so we remain confident that our data provide a relatively accurate picture of the state-by-state distribution of incidents. For these reasons, in the absence of data from the government or other sources, our data remain the most thorough and the most reliable currently available. 
One further issue worth noting is that many of our demographic statistics come from the last Indian census, which was conducted in 2001 (Office of the Registrar General 2001).This means that our demographic data is six to seven years removed from the incidents of violence. The lag is less of a problem on some measures than others. For example, the effect of differential growth on ethnic violence, it has been argued, is largely about perceived relative growth, and so one would assume changes in growth rate would have a lagging effect (Urdal 2008).

Statistics on the Christian and Hindu populations in 2001, the 1991-2001 Christian and Hindu decadal growth rates, and police presence data come from the Statistical Abstract India, 2004 (Office of the Registrar General 2004). Data on population density, scheduled caste (SC) population, scheduled tribe (ST) population, sex ratio, age distribution, literacy, employment and economic indicators come from the Census of India 2001 (Office of the Registrar General 2001). Electoral results for the 2004 and 2009 Lok Sabha elections come from the Election Commission of India (www.eci.nic.in).

\section{Methods}

Existing literature on political violence and Hindu-Muslim violence suggests that states experiencing violence against Christians may have unique dynamics falling into four categories: (1) demographic characteristics; (2) religion, caste and tribe dynamics; (3) political power and competition; and (4) human capital and relative deprivation. We explore each of these topics in separate sections below. The analyses are meant to be descriptive, so we rely heavily upon bivariate comparisons and comparisons of means tests.

Twelve of the thirty-five states experienced no violence against Christians between 2007 and 2008. Those that did recorded 1-167 events. (The 167 incidents in Karnataka was an outlier, with the next largest prevalence being sixty-one in Andhra Pradesh.) Our analyses compare the characteristics of states that experienced any violence against Christians to those that experienced none.

In recognition of potential cultural, social and economic differences by region, we analysed trends in specific regions - i.e. we performed subanalyses specific to states in the northeast, south and north. Overall, we identified few statistically significant relationships within regions, and the direction of relationships conformed to those presented in our results on the larger sample (with the exception of the north region, as presented in the 'Demographic characteristics' section). Beyond these general findings, the small number of states by region - for example, the south region only contains seven states and the northeast only contains eight - provides very little statistical power and makes us reticent to discuss any identified trends. We did, however, consistently make one geographic distinction that we identified as theoretically compelling and methodologically feasible.

Due to cultural, ethnic, linguistic and religious distinctions from the rest of India, we performed all of our comparisons on a subsample that excludes the northeastern region of India. Seventyseven per cent of the remaining states (twenty out of twenty-seven) experienced an incident of violence against Christians. For the sake of simplicity, and in the absence of established 
terminology, we will refer to this subsample of India excluding the northeast as 'Peninsular India'. Important to our analysis, this area of India has a significantly smaller concentration of Christians compared to the northeast (4 per cent versus 39 per cent, respectively).

\section{Demographic characteristics}

It is relatively widely attested in the extant literature that impoverished countries are more vulnerable to internal political violence (Collier and Hoeffler 2004; Urdal 2008). Similarly, resource-scarcity theorists posit that population growth and population density, combined with inadequate renewable natural resources, leads to competition and, in certain circumstances, violence between groups (e.g. Myers 1993; Homer-Dixon and Blitt 1998; Kahl 2006). This would indicate that ethnic violence is primarily an issue in low-income, urbanizing areas (Engineer 1984; Horowitz 2001), but the argument can be extended to rural areas. Urdal, for example, finds a positive association between rural population density and armed conflict, but no association between rural population density and Hindu-Muslim riots (Urdal 2008). Hudson and den Boer (2004) suggest that regions with a surplus of males (i.e. a higher sex ratio) are at greater risk of political violence, although Urdal (2008) does not find male surpluses to be a contributing factor in his analysis of Hindu-Muslim riots. Instead, youth bulges correlate positively with every kind of political violence in India, including Hindu-Muslim riots (2008). Other scholars contend that there is an inverse correlation between social control and political violence. According to this perspective, the more individuals or groups feel they can participate in violence against others without serious social or legal repercussions, the more the risk of violence increases. Thus, many theorists (Horowitz 1985; Kohli 1990; Tilly 2003) correlate 'state weakening' with ethnic violence.

Police presence is a passable index of state strength. The police in India are notoriously corrupt and ineffective, so much so that Brass (2003) doubts whether the addition of more or bettertrained police would lead to a decrease in Hindu-Muslim violence, and Wilkinson (2004) finds little support for state-weakening theories in his research on Hindu-Muslim violence.

Nevertheless, in part because of our intuition that Hindu-Christian violence takes place primarily in rural areas (where police presence is generally minimal), we tested, in this analysis, for possible correlations of police presence and Hindu-Christian violence.

In sum, the literature on the association of demographic variables and political violence might lead to the following hypothetical characterization of states experiencing an incident of violence against Christians: they are (1) poorer, (2) under-policed, (3) densely populated areas with a disproportionate number of (4) men and (5) young adults. Our data suggest that this is not an accurate depiction of areas that experience anti-Christian violence (Table 1). The presence of police is the only demographic characteristic that distinguishes states experiencing violence from others at the level of statistical significance. On average, states that do not experience violence against Christians have over twice the number of police per 100,000 people than states that experience violence.

Although it is not statistically significant, it should be recognized that the sex ratio trends in the direction expected by Hudson. For good measure, we explored the sex ratio of the 'youth bulge' in particular. There is no evidence that states that experienced violence had a larger 
concentration of young men. However, this represents the one area where subanalyses by region contradict the results for the overall sample, and differences are so large that we feel they are worth mentioning. As is indicated in Table 2, when comparisons are limited to the north region, the sex ratio and youth bulge are associated with the experience of violence against Christians. Compared to states not experiencing violence, these states have a higher concentration of men (sex ratio of 766 vs 922, respectively) as well as a larger portion of young adults (21 per cent vs 26 per cent, respectively).

These trends could be informative, but all of our information on demographic characteristics is measured based on information provided in the 2001 census, so our results should be interpreted cautiously. 2 This limitation could be especially important for the information about youth bulges since we utilized the percentage of the population aged seven to seventeen.

\section{Religion, caste and tribe characteristics}

Many social theorists have argued that an important factor in ethnic conflict is the relative increase or decline (or perceived increase or decline) of the ethnic groups involved (Horowitz 2001; Lake and Rothchild 2001; Toft 2002). In India, Hindu nationalists claim that Christians' aggressive evangelizing and free use of money and social services to 'lure' marginalized groups within Indian society (e.g. the lower castes and tribes) to the Christian fold will contribute to the growth of Christianity at the expense of Hinduism, framed in this discourse as a nonevangelizing and non-converting religion (S. Sarkar 1999, 2002; Bauman 2010). In the public discussion of Hindu-Muslim conflict in India, both Hindu nationalists and Muslims also assert that violence correlates positively with the proportion of Muslims in any given location, although their explanation for why this is so differs drastically (Varshney 2002). Contrary to both of these theoretical contentions, Wilkinson does not find a statistically significant correlation between the proportion of Muslims and the occurrence of Hindu-Muslim riots (Wilkinson 2004). Moreover, anecdotal evidence suggests that Christians are most likely to be targeted in areas where they are most vulnerable, that is, in areas where they do not constitute a significant proportion of the population.

Our data indicate inconsistent associations between anti-Christian violence and basic indicators of the size and growth of Hindu and Christian populations, respectively. Table 3 indicates a significant association with characteristics of the Christian population, but only when the heavily Christian northeast is included in the analysis. Analyses that exclude the northeast region indicate significant relationships between violence and characteristics of the Hindu population.

Our results are better understood if we consider differential growth rates. As Urdal (2008) notes, few attempts have been made to model the relationship of violence and differential growth rates. Toft's (2007) work on civil war is one exception. Toft finds increased risk of violence in contexts with a decreasing majority and a static minority, but does not find an increased risk of violence in societies with decreasing majorities and increasing minorities (Toft 2002). In contrast, Urdal's (2008) data demonstrate no significant relationship between differential growth rates and HinduMuslim riots. 
Our data are more in line with Toft's data, revealing interesting differences in differential growth rates between states that experience anti-Christian violence and states that do not. Figure 1 graphically depicts the percentage of states experiencing violence when Hindu and Christian growth rates are considered simultaneously. The primary distinction occurs where states have a Hindu population that is increasing much faster (more than 5 per cent greater increase) than the Christian population. More than twice as many states experienced violence if they fell into the categories of the Christian population increasing at a similar or faster rate ( \pm 5 per cent) than the Hindu population.

There is also reason to expect Hindu nationalists to feel threatened by Christians where there is growing political and numerical power of the SCs and STs (Appadurai 2006). It is commonly asserted by critics of Hindu nationalism that its anti-minority tendencies are fueled by a central core of upper-caste Hindu leaders who sense (and fear) that their traditional political, social and economic advantages are being eroded by India's democratic governance and affirmative actionstyle system of political, vocational and educational reservations for members of what are officially called 'Scheduled Castes' (i.e. the lower castes, or dalits), and 'Scheduled Tribes' (i.e. tribal groups that have traditionally been on the margins, culturally and geographically, of Hindu and Indian society). Lobo (2002, p. 9), for example, argues that 'in the context of globalization, Hindu nationalists are fighting a last-ditch attempt by deceit, cunning and cleverness to clandestinely retain the Brahminical [i.e. upper-caste] hegemony and advancement of political privileges, which they had been continuously enjoying for centuries.' If these theories were correct, then one would expect to see violence against Christians in states with small and/or declining upper-caste communities, both because Christians are minorities and because so many of them converted from SC and ST communities. Referring back to Table 3, our results indicate that the SC percentage is positively correlated with anti-Christian violence, but the ST percentage is negatively correlated. These results are consistently significant whether the northeast is excluded or not.

\section{Political power}

The role of fear and power struggles most obviously extends to political considerations. Within social democracies such as India, the numerical decline of a majority portends its political weakening. Hindu nationalists in India have been largely unsuccessful in gaining the electoral support of religious minorities (Maclean 1999). Many popular and scholarly commentators, therefore, view the Hindu nationalist stigmatization and/or targeting of minorities as an instrumentalist ploy intended to consolidate the 'Hindu' vote (Zavos 2001). In turn, it is a widely espoused, 'common sense' assumption that violence against minorities is (and will be) higher in states where the BJP and/or its National Democratic Alliance (NDA) allies are in power, because of their alleged at least tacit support of it.

Some scholars, however, argue that the relationship between political power and violence is more complex. According to Gupta (2007, p. 28): ‘[M]ultiple religious solitudes are perfectly capable of co-existing with one another so long as the power asymmetries between adherents of different faiths are so vast that there is no room for contest. After all, only equals fight ....' Wilkinson's (2004, pp. 43-4) research on Hindu-Muslim violence provides some support for this expectation that political competition correlates with violence: 
Having a close race in the previous state legislative election has a clear substantive effect: holding all other variables constant having a margin of $5 \%$ or less in the previous election leads to a predicted 0.003 riots per month, compared with 0.0009 riots in a town with wider election margins in the previous race.

Table 4 shows that, on average, the NDA occupied about six Lok Sabha seats in states that experienced violence against Christians, versus less than one in the states that saw no violence.3 Furthermore, in the most recent election before the violent incidents (2004), the NDA garnered over one third of the vote in areas with violence against Christians, but only one fourth of the vote in the remaining areas. These results indicate that violence is more prevalent in areas where the NDA has greater political power.

We also investigated the contention that the closer parties get to parity in an election, the greater the violence in the run-up to the subsequent election by generating a measure of the absolute value of the NDA's distance from 50 per cent of the total vote. The results reveal that, on average, the NDA is closer to parity in the states where violent events occur (13 per cent) than in other states (25 per cent). It should be recognized that, although this measure is theoretically an absolute value, it is largely a measure of how close the NDA came to gaining 50 per cent of the vote. The NDA only garnered 50 per cent of the vote in one state (Arunachal Pradesh). In the remaining states, the NDA garnered anywhere from 0 per cent to 45.5 per cent of votes in the 2004 election.

Although there are dissenting voices (T. Sarkar 2002) and recent election results might suggest otherwise, many claim that the instrumental use of violence by the BJP and its nationalist allies works to their political advantage, that they know this, and that they for this reason continue to stoke anti-minority sentiment and condone (if not provoke) anti-minority violence (Brass 2003). Sunder Raj, Thambusamy and Samuel (2000) and Lobo (2002) point out, for example, that after the anti-Christian riots in Dangs, Gujarat (1998), the BJP picked up a record number of seats in the region. Our data do not support this contention for the whole of India.

Figure 2 presents information about the change in the NDA's representation in government between 2004 and 2009. The NDA did not gain a seat in any of the states during this period, so we have broken states into those that did not lose an NDA seat $(n=17)$, those that lost fewer than ten seats $(n=11)$ and those that lost more than ten seats $(n=7)$. The graph shows that every state where the NDA lost more than ten seats had experienced an incidence of violence against Christians in 2007-8. Fewer than half (41 per cent) of the states that maintained all of their NDA seats had experienced violence against Christians in the previous year. This trend of a loss of NDA seats in the year following a violent event does not support the contention that violence against Christians increases the political power of Hindu nationalists.

\section{Human capital and relative deprivation}

Beyond these political considerations, scholars and policy makers commonly propose that political violence is the consequence of low aggregate levels of human capital - i.e. accumulated skills and personal attributes associated with economic success in a particular social context. 
Proponents of this perspective tend to focus on under-employment (which leads to social unrest) and/or lower levels of education (which, according to this theory, decreases the likelihood that a population will seek solutions to its grievances through legitimate political processes). Existing analyses of under-employment reveal associations with terrorist violence in Algeria (Kouaouci 2004), ethnonationalist violence in Ireland (Maney 2005) and violent crime in India (Drièze and Khera 2000). Similarly, literacy and education correlate negatively with criminal violence (Drièze and Khera 2000) and domestic violence in India (Menon and Johnson 2004). Notably, however, Lange and Dawson (2010) find that educational levels correlate positively with ethnic violence in a number of national contexts.

Table 5 provides information about human capital and its relationship to violence against Christians at the state level. These considerations seem to be particularly important in Peninsular India. States experiencing violence against Christians have low rates of literacy and work participation among Hindu men, and also have low rates of work participation among Christian men. In general, violence against Christians seems to be occurring in areas with less human capital.

In addition to inter-state disparities in human capital, extant literature provides compelling reasons to explore intra-state disparities between Hindus and Christians on these same indices. Engineer (1984) argues that economic competition and rivalries are at the heart of many HinduMuslim riots. One of the frequent claims of Hindu nationalists is that violence against Christians is a 'natural' response to Christian conversion activities, which are funded by western wealth and intended to lure impecunious and presumably easily duped members of the lower castes and tribes to convert (Tripathy 2008). This activity is deemed illegitimate because it leads, so the assertion goes, to a kind of undeserved (and foreign-funded) advance in education, wealth and social status (Bauman 2010).

If such assertions are influencing behaviour, then we would expect to see more incidents of violence in states where Christians approach or outpace Hindus on economic and educational indicators. We investigated Christian/Hindu differentials in literacy rates (not shown) and found no significant association with incidents of violence against Christians. However, Figure 3 displays results on employment differentials, and these data support the proposition that economic competition could be connected to Hindu-Christian violence. More than three-quarters of states where Christians are approaching employment parity with Hindus experienced violence compared to less than a third of those where Christians are more severely under-employed.

\section{Discussion and conclusions}

While our reported trends provide at least some support for a variety of theses about ethnic conflict and/or political violence, we find that they more generally call for increased exploration of perceived threat hypotheses. Due to great cultural and economic variation by region, more direct and simplistic macro-level explanations may be appropriate on a sub-national basis (indeed, our analyses indicate that demographic factors may be particularly important in the north). Nonetheless, at the national level, our most consistent findings indicate that relative measures of ethnic minorities' status (e.g. parity in Hindu/Christian employment status) are more telling than basic measures of their status (e.g. Christian employment rate). In sum, our results 
should encourage future, macro-level (especially demographic) researchers to pay specific attention to indicators of perceptions of Christian economic, social and political status rather than their objective share of resources.

The conceptual explanation for these dynamics necessarily assumes that violence against Christians is condoned and promoted primarily by organizations associated with the Sangh Parivar and political parties associated with the NDA, and that these organizations and parties are animated by a fear of declining Hindu political and economic power (particularly upper-caste Hindu power). 4 Given the fact that Hindus constitute roughly 80 per cent of the Indian population, there is no real, short-term threat to their numerical dominance. However, because of the heterogeneous and fractious nature of the 'Hindu' population, the large number of more secularist Hindus, as well as the substantial number of SC Hindus who frequently vote against nationalist parties and policies due to their perceived upper-caste bias, it is easy to see why the core nationalist constituency may consider itself a threatened minority. This is particularly true in the presence of real threats, such as relatively low Hindu growth rates, the presence of large SC communities (and therefore of smaller upper-caste communities), and signs that the Christian minority has become - or is in a position to become - a serious contender in the job market. In such a context, and when elections are close, the employment outlook pessimistic, educational achievement low, and social control weak, nationalist politicians and their supporters may be expected to resist their declining political power by instrumentalizing communal identities through the stigmatization of, or the explicit or implicit support for, violence against Christians (even though the data suggest that such instrumentalization may be counterproductive).

The importance of perceived threat is evidenced in our results on the size and growth of the Christian and Hindu populations, political power and economic indicators. The inverse relationship between violence and both Christian population size and growth is inconsistent with the literature, but we find that differential Hindu-Christian growth is negatively related to violence, especially in Peninsular India. Peninsular states where Christian growth rates approach or exceed that of Hindus are more than twice as likely to experience violence compared to states where Hindu growth rates are higher. Our results, therefore, provide support for differential growth theories advanced by Horowitz (2001), Lake and Rothchild (2001), Toft (2007) and Weiner (2001).

In a similar way, our results on political power draw attention to perceived political threat. Instrumentalist political theories like those espoused by Basu (1995), Engineer (1984), Joshi (1999) and Sunder Raj, Thambusamy and Samuel (2000), which contend that Hindu nationalist parties intentionally provoke (or at least condone) anti-minority violence for what they believe will be their political advantage, receive some support from our discovery that states that experience violence have more Lok Sabha seats occupied by the NDA. However, our analyses also indicate that violence is more likely to occur in states where voting for political parties approaches parity. These discoveries echo those of Wilkinson (2004), who found the same for Hindu-Muslim violence. So while the association is not particularly robust, the data, on the whole, highlight both the perceived political threat perspective and instrumentalist political theories. 
Whether the instrumentalization of anti-Christian violence actually works, as Brass (2003) has suggested, is another question altogether. One of the most intriguing results of our analysis was that the NDA was far more likely to lose Lok Sabha seats in the 2009 elections in states where there had been anti-Christian violence in 2007-8, and that all of the states where the NDA had lost ten or more seats had experienced violence in that period. We discern two possible explanations for this result. The first is that violence against Christians actually works against the very parties that are perceived to provoke or condone it, that is, that anti-Christian violence incites an anti-nationalist backlash. The second is that NDA politicians, and their supporters, are more likely to provoke or condone violence when they perceive their political support to be in decline. Only further research could explain with more confidence whether violence or declining NDA political power is the more influential factor.

Finally, our data provide some support for human capital hypotheses, especially those that emphasize perceived economic threats. Although Christian literacy rates are unrelated to antiChristian violence, Hindu literacy rates and Hindu work participation rates are negatively related to violence. More importantly, and more consistently, the all-India data demonstrate a rather strong association of relative work deprivation and violence. As Christians approach or surpass Hindus in work participation, the proportion of states experiencing violence increases dramatically, and subsequent analyses (not shown) indicated that the association was particularly strong in the case of male employment. These results are theoretically and socially important because of the Hindu nationalist claim that Christians use education and work opportunities to lure Hindus to the Christian fold. Whether they do or do not is beyond the scope of this analysis, but the data suggest, at the very least, that economic competition (or - considering the effect of Christians approaching parity with Hindus - the perception of competition) is one factor in Hindu-Christian violence.

Although they provide less consistent information, it is still worth discussing our results on basic demographic and social characteristics of state populations that experience violence. Our subnational results for north India complement Urdal's finding that male surpluses (admittedly measured in 2001) correlate somewhat positively with political violence, at least when combined with youth bulges. But at the national level, our data on Hindu-Christian violence lead us to echo Urdal's (2008, p. 605) assertion that 'demographic variables appear to matter little to the production of Hindu-Muslim riots in India ....' At the national level, the sole demographic characteristic related (inversely) to the probability of violence was police presence. These data, then, are in line with Horowitz's (1985) hypothesis that absence of social control may contribute to an increase in violence, and provide indirect support for the state-weakening theories advanced by Horowitz (1985), Kohli (1990), Tilly (2003) and others. These results may also encourage future researchers to reassess Wilkinson's general scepticism of state-weakening theories as explanations for communal violence.

It is worth noting, for the benefit of future research, several ways in which our data and analyses might be refined and improved. First, the data should be further disaggregated, at least to the district level, so that one violent city or region cannot taint an entire state's risk profile. In addition, it may be useful to utilize state assembly rather than Lok Sabha electoral results. Moreover, since India's is a first-past-the-post democracy in which political parties commonly win with far less than 50 per cent of the vote, it may be useful to statistically explore whether 
violence peaks at some percentage lower than 50 per cent rather than to conceive of 'parity' as proximity to 50 per cent (as we did). Our own preliminary investigation (not shown) suggests that that violence does indeed peak when the NDA receives around 35 per cent of the vote in Lok Sabha elections. Further analysis would also benefit from a time-series study utilizing available data on anti-Christian violence over a longer span of time. Such a study would help minimize the effects of relying on decadal census data. Finally, the use of multiple data sets on anti-Christian violence would control for potential biases.

There are also a number of potentially fruitful lines of inquiry that we were not able to investigate. For example, Varshney's (2002) persuasive thesis on the importance of civic engagement in reducing the risk of Hindu-Muslim riots should be tested in the context of Hindu-Christian conflict. In addition, much recent research (Lobo 2002; Appadurai 2006; Ahmad 2007) asserts a link between globalization and ethnic violence in India. This thesis could be tested by developing an index of globalization (the presence of multinationals, foreign direct investment, etc.) and testing it for correlations with violence. It would also be worth investigating possible spillover effects from neighbouring areas, as Urdal (2008) has done, as well as whether earlier incidents of violence increase the probability of future violence, as Horowitz (2001) suggests.

In addition to these lines of inquiry, any more thorough analysis of violence against Christians must test the regular Hindu nationalist claim that anti-Christian violence is provoked by the aggressive evangelizing of Christian missionaries. If this were true, then we would expect to see an increase in violence in regions with more (or more aggressive) missionaries. A cursory review of our data on violence against Christians suggests, for example, that Pentecostal, Charismatic and Independent Evangelical Christians are disproportionately targeted while members of the Roman Catholic Church, older European and North American Protestant denominations, the Church of North India and the Church of South India are rarely among the list of victims, despite constituting around 50 per cent of Indian Christians (Barrett, Kurian and Johnson 2001). These latter, more mainstream denominational Christians in India often blame the ostensibly more offensive evangelizing methods of Pentecostals, Charismatics and Independent Evangelical Christians for anti-Christian violence (Baldauf 2005). Reliable data on the distribution of various kinds of Christian denominations, missionaries and missionary organizations is, however, unfortunately incredibly difficult to come by, and even more so these days given the fear, on the part of Christians, that such data might be used by Hindu nationalists to stoke anxieties about Christian growth or to target certain Christian communities. Only with better data could such hypotheses be tested.

\section{Acknowledgements}

The authors would like to thank the Center for Religion and Civic Culture at the University of Southern California and the John Templeton Foundation for a generous grant that supported this research, and Ariel Tyring for help in developing the study database.

\section{Notes}


1. We follow Varshney (2002) in using 'ethnic' in a broader sense; one that includes within the term any ascriptive grouping (linguistic, religious, tribal, caste, racial, etc.).

2. Given the chronological distance of our census data (2001) from our data on attacks against Christians (2007-8), we examine the correlation between percentage of the population aged seven to seventeen in 2001 and incidents of violence in 2007-8.

3. We initially investigated indicators of BJP political power in addition to measures of NDA political power. These analyses revealed the same pattern of associations with violence against Christians (and they are available upon request to the authors). However, the correlations were stronger and more consistently significant when measures were specific to the NDA.

4. Indian censuses do not directly record data on the numbers or proportions of various castes, so the inverse of the SC population becomes the best possible indicator of the size of the middleand upper-caste Hindu population. 


\section{References}

1. Aaron, S. 2002. Christianity and Political Conflict in India: The Case of Gujarat, Colombo: Regional Centre for Strategic Studies.

2. Ahmad , A. 2007 On Communalism and Globalization: Offensives of the Far Right, , 2nd edn , Gurgaon : Three Essays Collective [1st edn 2004]

3. Appadurai, A. 2006. Fear of Small Numbers: An Essay on the Geography of Anger, Durham, NC: Duke University Press.

4. Baldauf , S. 20051 April A new breed of missionary: a drive for conversions, not development, is stirring violent animosity in India , Christian Science Monitor Online , Available from: http://www.csmonitor.com/2005/0401/p01s04-wosc.html

5. Barrett, D. B., Kurian, G. T. and Johnson, T. M. 2001. World Christian Encyclopedia: A Comparative Survey of Churches and Religions in the Modern World, New York: Oxford University Press.

6. Basu, A. 1995. Why Local Riots Are Not Simply Local: Collective Violence and the State in Bijnor, India 1988-1993. Theory and Society, 24: 35-78. doi:10.1007/BF00993322.

7. Bauman, C. 2010. "Identity, conversion and violence: dalits, adivasis and the 2007-08 riots in Orissa”. In Margins of Faith: Dalit and Tribal Christianity in India, Edited by: Robinson, R. and Kujur, J. M. 263-290. Washington, DC: Sage.

8. Brass, P. R. 2003. The Production of Hindu-Muslim Violence in Contemporary India, New Delhi: Oxford University Press.

9. Chatterji, A. 2009. Violent Gods: Hindu Nationalism in India's Present; Narratives from Orissa, Gurgaon: Three Essays Collective.

10. Collier, P. and Hoeffler, A. 2004. Greed and grievance in civil war. Oxford Economic Papers, 56(4): 563-95. doi:10.1093/oep/gpf064.

11. Drièze, J. and Khera, R. 2000. Crimen, género y sociedad en India: observaciones de datos de homicidios. Population \& Development Review, 26(2): 335-52. doi:10.1111/j.17284457.2000.00335.x .

12. Engineer, A. A. 1984. "The causes of communal riots in the post-partition period in India”. In Communal Riots in Post-Independence India, Edited by: Engineer, A. A. 33-41. Bombay: Sangam Books.

13. Froystad, K. 2009. Communal riots in India as a transitory form of political violence: three approaches. Ethnic and Racial Studies, 32(3): 442-59. doi:10.1080/01419870701722315. 
14. Gupta, D. 2007. Citizens versus people: the politics of majoritarianism and marginalization in democratic India. Sociology of Religion, 68(1): 27-44.

doi:10.1093/socrel/68.1.27.

15. Hardiman, D. 2002. “Christianity and the adivasis of Gujarat”. In Development and Deprivation in Gujarat: In Honour of Jan Breman, Edited by: Shah, G., Rutten, M. and Streefkerk, H. 175-195. London: Sage Publications.

16. Homer-Dixon, T. F. and Blitt, J. 1998. Ecoviolence: Links among Environment, Population and Security, Lanham: Rowman \& Littlefield.

17. Horowitz, D. 1985. Ethnic Groups in Conflict, Berkeley, CA: University of California Press.

18. Horowitz D. 2001 The Deadly Ethnic Riot , Berkeley, CA : University of California Press

19. Hudson, V. M. and Den Boer, A. M. 2004. Bare Branches: The Security Implications of Asia's Surplus Male Population, Cambridge, MA: MIT Press.

20. Jaffrelot , C. 2007 Hindu Nationalism: A Reader, Princeton , NJ : Princeton University Press

21. Joshi, S. 1999. Tribals, Missionaries, and Sadhus: Understanding Violence in the Dangs. Economic and Political Weekly, 34(37) September 11: 2667-2675.

22. Kahl, C. H. 2006. States, Scarcity, and Civil Strife in the Developing World, Princeton, NJ: Princeton University Press.

23. Kohli, A. 1990. Democracy and Discontent: India's Growing Crisis of Governability, New York: Cambridge University Press.

24. Kouaouci, A. 2004. Population transitions, youth unemployment, postponement of marriage and violence in Algeria. Journal of North African Studies, 9(2): 28-45.

doi:10.1080/1362938042000323329

25. Lake, D. and Rothchild, D. 2001. "Containing fear: the origins and management of ethnic conflict”. In Nationalism and Ethnic Conflict, Edited by: Brown, M. E. 203-226. Cambridge, MA: MIT Press.

26. Lange, M. and Dawson, A. 2010. Education and ethnic violence: a cross-national timeseries analysis. Nationalism and Ethnic Politics, 16(2): 216-39.

doi:10.1080/13537113.2010.490758

27. Lobo, L. 2002. Globalisation, Hindu Nationalism and Christians in India, 1-19. New Delhi: Rawat Publications. 
28. Maclean, K. K. 1999. Embracing the untouchables: the BJP and scheduled caste votes. Asian Studies Review, 23(4): 488-509. doi:10.1080/10357829908713252

29. Maney, G. M. 2005. Variations in the causes of ethnonationalist violence: Northern Ireland, 1969-72. International Journal of Conflict Management, 16(1): 70-96. doi:10.1108/eb022924

30. Menon , N. and Johnson , M. P. 2004 A feminist study of domestic violence in rural India , in American Sociological Association, Conference Papers: American Sociological Association Annual Meeting . San Francisco , CA : American Sociological Association

31. Myers, N. 1993. Ultimate Security: The Environmental Basis of Political Stability, 1-19. New York: Norton.

32. Office of the Registrar General and Census Commissioner 2001 Census of India, 2001 , New Delhi : Controller of Publications (36 volumes)

33. Office of the Registrar General and Census Commissioner 2004 Statistical Abstract, India, 2004 , New Delhi : Controller of Publications

34. Pandey, G. 1990. “The colonial construction of "communalism”: British writings on Banaras in the nineteenth century". In Mirrors of Violence: Communities, Riots and Survivors in South Asia, Edited by: Das, V. Delhi: Oxford University Press.

35. Pandey G. 2006 Routine Violence: Nations, Fragments, Histories , Delhi : Permanent Black [1st edn 2005]

36. Sarkar, S. 1999 Conversion and politics of Hindu right, Economic and Political Weekly 26 June 199934,26 , 1691700

37. Sarkar, S. 2002. "Christianity, hindutva, and the question of conversions". In Beyond Nationalist Frames: Postmodernism, Hindu Fundamentalism, History, Edited by: Sarkar, S. 215-43. Indianapolis, IN: Indiana University Press.

38. Sarkar T. 2002 Semiotics of terror: Muslim children and woman in Hindu Rashtra , Economic and Political Weekly 13 July 20023728 , 2872 - 76

39. Sunder Raj , E. , Thambusamy , S. and Samuel , E. 2000 Divide to Rule: Communal Attacks on Christians in India during 1997-2000: Full Details, Reasons, Allegations and Answers , Chennai : Bharat Jyoti [1st edn 1999]

40. Tilly, C. 2003. The Politics of Collective Violence, New York: Cambridge University Press.

41. Toft, M. D. 2002. Differential demographic growth in multinational states: Israel's twofront war. Journal of International Affairs, 56(1): 71-94. 
42. Toft M. D. 2007 Population shifts and civil war , International Interactions , 33 , 3243 69 doi: 10.1080/03050620701449025

43. Tripathy , R. P. 2008 Pseudo-seculars deliberately trying to shun facts , Kamal Sandesh , 1-15 February , 20 - 2

44. Urdal, H. 2008. Population, resources, and political violence. Journal of Conflict Resolution, 52(4): 590-617. doi:10.1177/0022002708316741

45. Varshney, A. 2002. Ethnic Conflict and Civic Life, New Haven, CT: Yale University Press.

46. Wilkinson, S. 2004. Votes and Violence: Electoral Competition and Ethnic Riots in India, Cambridge: Cambridge University Press.

47. Zavos, J. 2001. Conversion and the assertive margins. South Asia: Journal of South Asian Studies, 24(2): 73-89. doi:10.1080/00856400108723451 
Table 1. Demographic characteristics of states experiencing at least one incident of violence against Christians versus states experiencing no violence

Mean value for states with violence

$$
(n=23)
$$

Households with no assets

$37 \%$

Police per 100,000 population

Population density

Sex ratio

Youth bulge (age seven to

seventeen in 2001)

Sex ratio of youth bulge

${ }^{\star * *} p<.001$.
Mean value for states with no violence

$$
(n=12)
$$

$32 \%$

4.47

1,199

938

$25 \%$

942 
Table 2. Demographic characteristics of states experiencing at least one incident of violence against Christians versus states experiencing no violence, north region only

Mean value for states with violence

$$
(n=3)
$$

$26 \%$

2.17

3254

$766^{\star * *}$

$21 \%$ **

901
Mean value for states with no violence

$$
(n=17)
$$

Households with no assets

$31 \%$

Police per 100,000 population

1.7

Population density

892

Sex ratio

922

Youth bulge (age seven to

seventeen in 2001)

Sex ratio of youth bulge 
Table 3. Religious, caste and tribe characteristics of states experiencing at least one incident of violence against Christians compared to states experiencing no violence against Christians

Indian states

Peninsular states

$\%$ in states with $\%$ in states with no \% in states with \% in states with no

$\begin{array}{llll}\text { violence } & \text { violence } & \text { violence } & \text { violence } \\ (n=23) & (n=12) & (n=23) & (n=12)\end{array}$

Christian

$5^{\star}$

26

3

6

population

Increase in

$34^{*}$

70

35

45

Christian

population

Hindu population $76^{*}$

52

78

70

Increase in Hindu 19

24

$20^{*}$

35

population

Scheduled castes $15^{\star *}$

5

$16^{\star *}$

6

Scheduled tribes $10^{\star * *}$

47

$8^{*}$

29

${ }^{*} p<.05,{ }^{* *} p<.01,{ }^{* * *} p<.001$. 
Table 4. Electoral votes and political seats garnered by the NDA in states experiencing at least one incident of violence against Christians compared to states experiencing no violence against Christians (based on the 2004 elections)

$$
\text { Indian states }
$$

$\begin{array}{cc}\text { Mean value in } & \begin{array}{c}\text { Mean value in } \\ \text { states with no } \\ \text { states with violence } \\ \text { violence }\end{array} \\ (n=23) & (n=12)\end{array}$

0.42

$26 \%$

$25 \%$

\section{Penisular states}

Mean value in

Mean value in states with violence

$$
(n=21)
$$

6.24 states with no violence

$$
(n=6)
$$

0.50

NDA share of votes $37 \%$

$39 \%$

Margin of victory $13 \%{ }^{*}$

$12 \%$

$38 \%$

$p<.10,{ }^{*} p<.05$. 
Table 5. Human capital of men in states experiencing at least one incident of violence against Christians compared to that in states experiencing no violence against Christians

Indian states

Peninsular states

$\%$ in states with $\%$ in states with no $\%$ in states with \% in states with no

$\begin{array}{lccc}\text { violence } & \text { violence } & \text { violence } & \text { violence } \\ (n=23) & (n=12) & (n=21) & (n=6)\end{array}$

Hindu literacy rate 79

82

79*

86

Christian literacy 83

81

84

89

rate

Hindu work

$53^{\star \star *}$

63

$53^{\star \star *}$

64

participation

Christian work 52

54

$52^{*}$

60

participation

${ }^{*} p<.05,{ }^{* * *} p<.001$. 
Figure 1. Percentage of states experiencing an incident of violence against Christians by differential growth rates in religious groups $n$ for each category is indicated at the centre of the bar.

${ }^{*} p \leq .05$ compared to Hindus increasing faster.

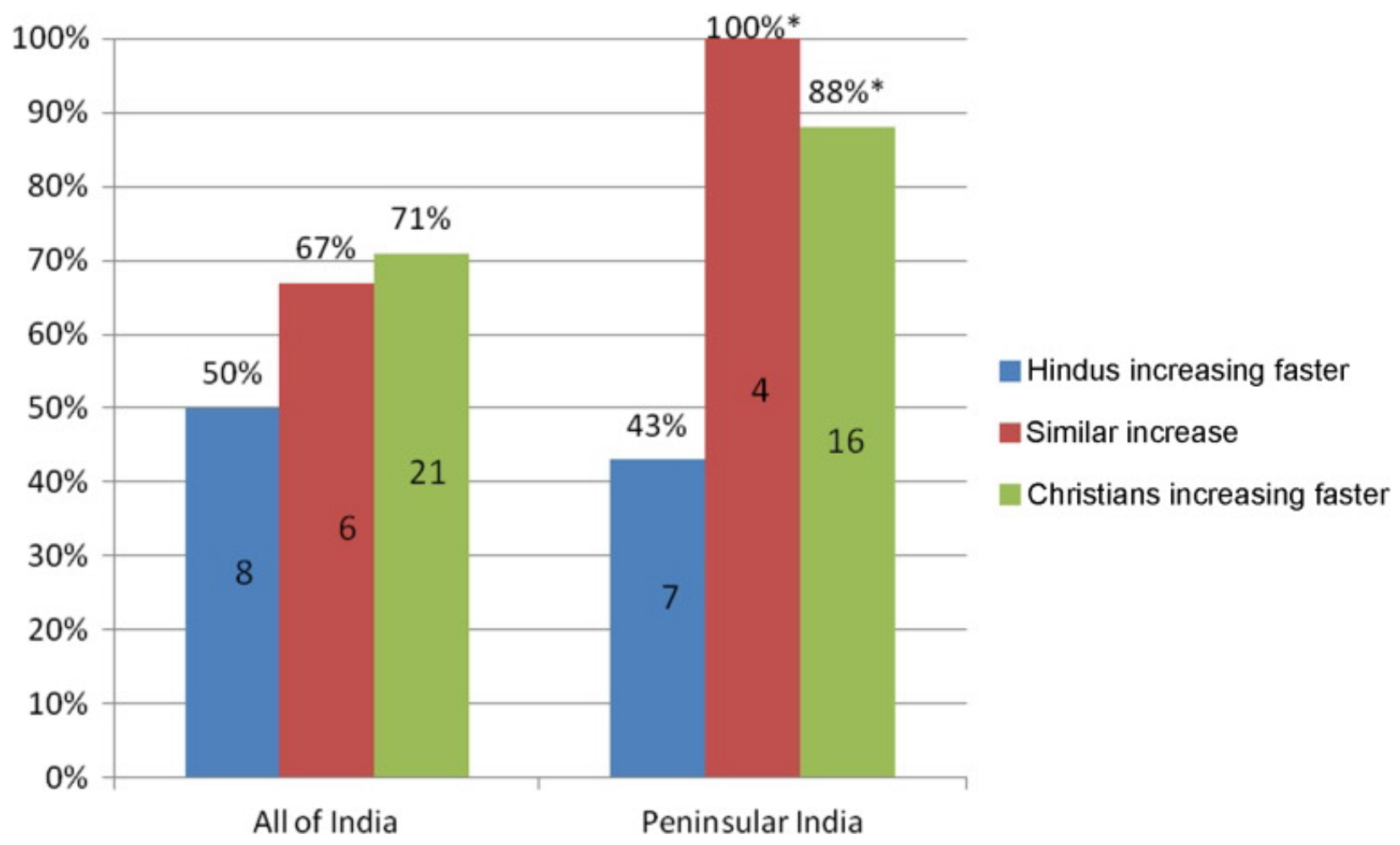


Figure 2. Percentage of states experiencing violence in 2007-8 by the number of NDA seats lost in the 2009 election

${ }^{*} \mathrm{p} \leq .05$ compared to 'no seats lost'.

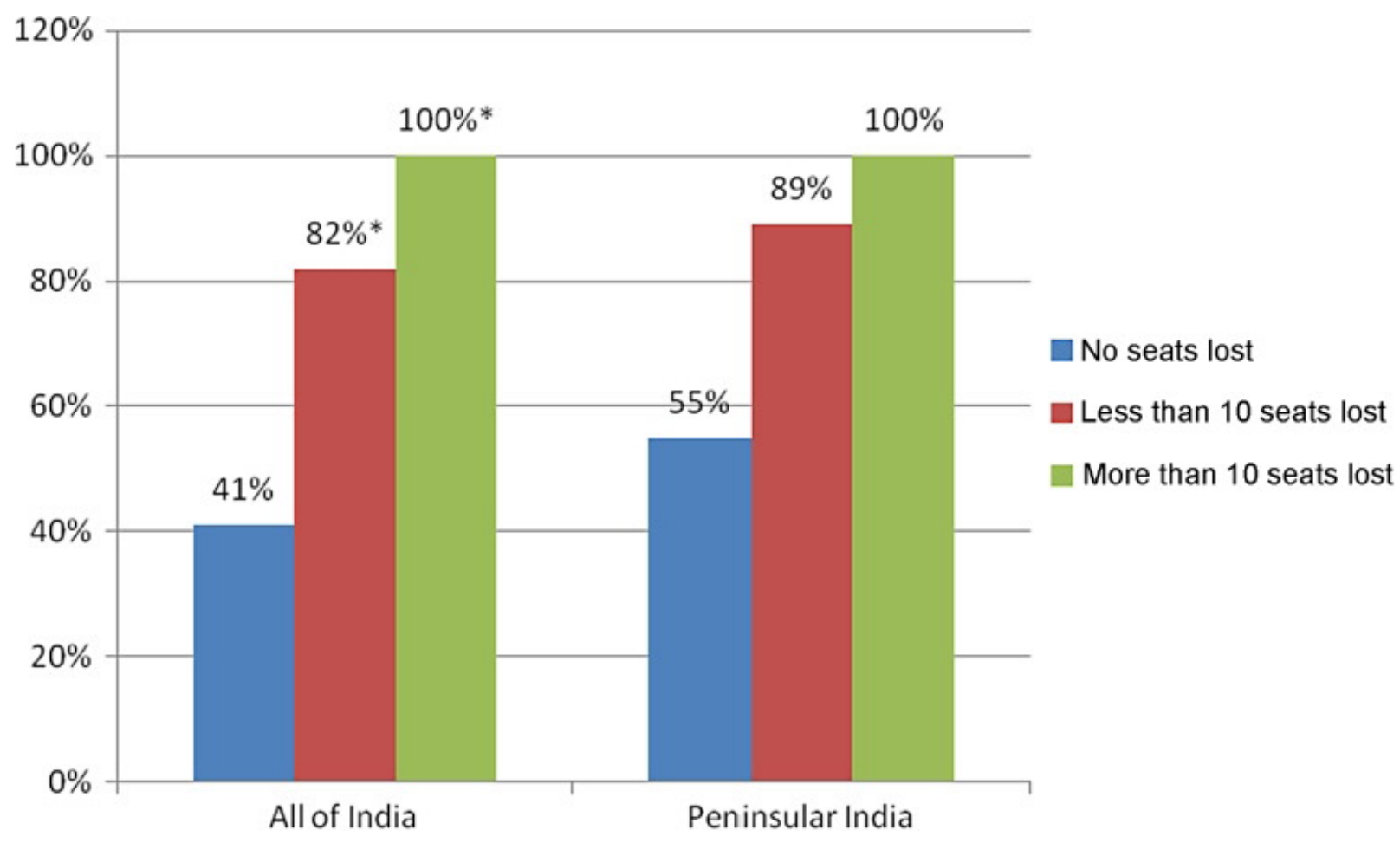


Figure 3. Percentage of states experiencing an incident of violence against Christians by Christian men's employment status relative to Hindu men

${ }^{1}$ Christian work participation is more than 5 per cent lower than Hindu work participation rate.

${ }^{2}$ Christian work participation is $1-5$ per cent lower than Hindu work participation rate.

${ }^{3}$ Christian work participation is equal to or higher than Hindu work participation rate.

$* \mathrm{p} \leq .05$ compared to areas where Christians are unemployed.

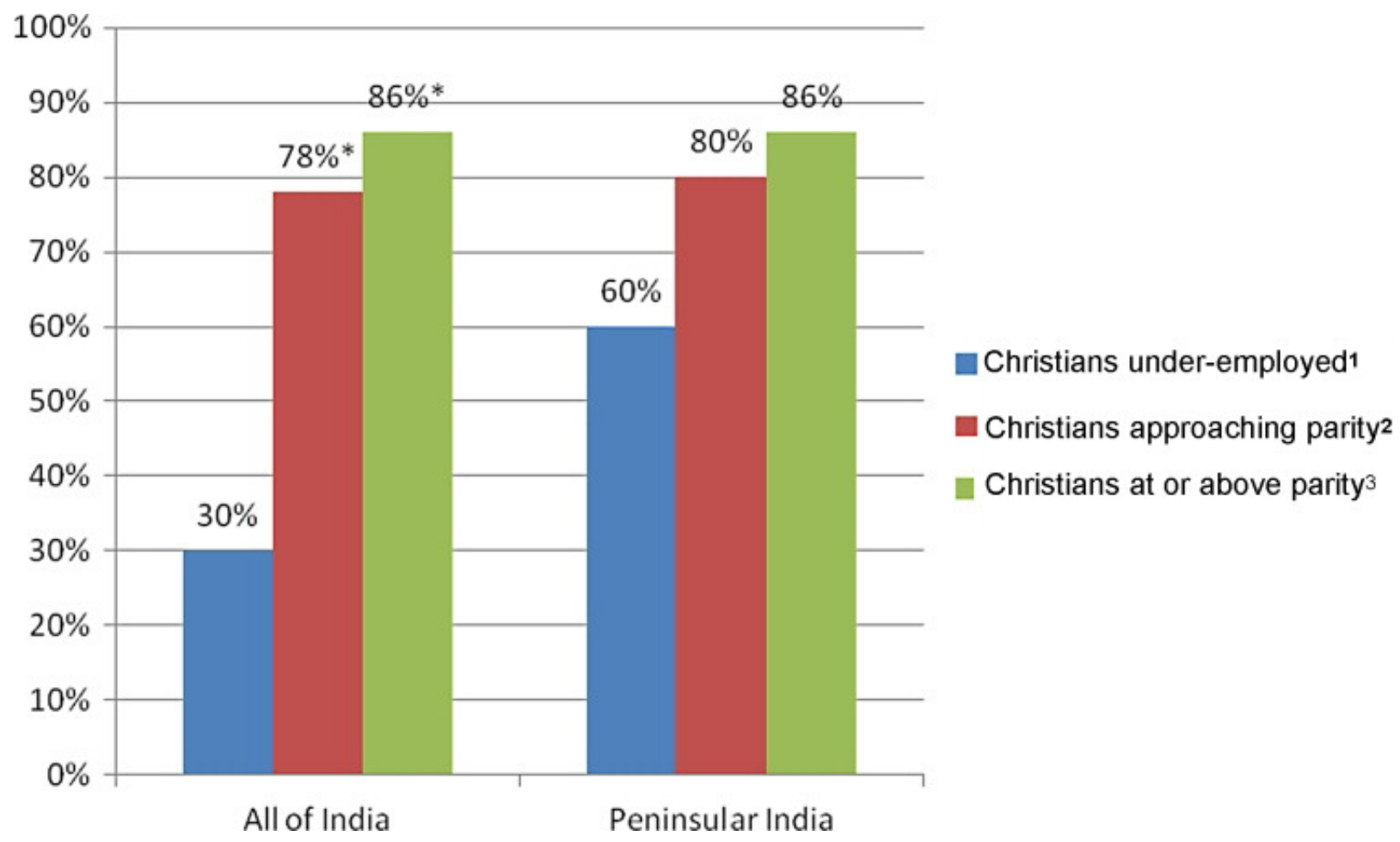

